\title{
Influence of Debt Maturity on Firm Performance: An International Comparison
}

\author{
Ben Said Hatem ${ }^{1}$ \\ ${ }^{1}$ Faculty of Law, Economics and Management of Jendouba, University of Jendouba, Jendouba, Tunisia \\ Correspondence: Ben Said Hatem, Faculty of Law, Economics and Management of Jendouba, University of \\ Jendouba, Jendouba, Tunisia. E-mail: hatbensaid@ gmail.com
}

Received: April 5, 2016

Accepted: April 5, 2017

Online Published: April 15, 2017

doi:10.5539/ijef.v9n5p106

URL: https://doi.org/10.5539/ijef.v9n5p106

\begin{abstract}
This paper manipulate the effect of capital structure maturity on firm performance. Debt maturity is measured by three ratios (the long term capital structure, the short term capital structure and total debt ratio). We test a sample consisting of 116 firms from Malaysia and 92 firms from Mexico over a period of 7 years from 2005 to 2011. We could not find evidence on the effect of the long term capital structure ratio on firm performance for specification 5 for Mexico. However, firms with higher short term capital structure ratio, are less profitable. This result is valid for firms from Malaysia and Mexico. The results of total debt ratio are mixed. We conclude to a positive effect for specification 4 for Malaysia and a negative effect for other specifications for Malaysia and Mexico.
\end{abstract}

Keywords: long term debt ratio, short term debt ratio, total debt ratio, maturity

\section{Introduction}

Ben said (2012) tried to identify factors that can explain firm performance. The author made a comparison between European countries. He concluded to differences between firms in terms of age, cash ratio and firm size. Akintoye (2009) founded that firm performance can be influenced by volatility of firm activity. Abor (2005) found a negative impact of long term debt ratio on firm performance estimated by return on equity. Furthermore, Huang and Song (2006); Chakraborty (2010) showed that firms with higher debt ratios have low profitability. Serghiescu and Vaidean (2013) found a negative influence of leverage on firm performance. Our paper tries to determine the effect of capital structure maturity on firm performance. We examines a sample of two countries: Malaysia and Mexico. The next section will review studies on the determinants of firm performance. In Section 3 , we present our sample, models and our variables. Section 4 reports the descriptive statistics and our empirical findings. A sensitivity analysis of our finding by activity is made in section 5 . The last section reports our main results.

\section{The Literature Review}

Following Roden and Lewellen (1995), Majumbar and Chhibber, (1999), Hadlock and James (2002), Abor (2005), Mahfuzah and Yadav (2012) tested the effect of capital structure on firm performance. As dependent variables, the authors use four performance approximations; Return on assets (ROA), return on equity (ROE), earnings per share (EPS) and Tobin Q. As for debt maturity, they use three measures of debt ratios. Examining a sample of 237 Malaysian firms over a period of 17 years from 1995 to 2011, the authors concluded average values of ROA, ROE, EPS and Tobin's Q are equal to 0.034562, 0.03, - 0.69131 and 0.7812 respectively. Furthermore, Mahfuzah and Yadav (2012) conclude that Malaysian companies finance their assets manipulating both short-term and long-term capital structure. This result says that Malaysian companies are less risky. The findings presented a negative and a statistically significant impacts of the three debt measures on firm performance (return on assets, return on equity ratio, and earnings per share).

Similar to the works of Andrade and Kaplan (1998), Shleifer and Vishny (1992), Opler and Titman (1994), Altman and Hotchkiss (2006) and Bris, Welch, and Zhu (2006), Victor (2013) highlight the effect of debt on firm performance. Examining a sample of 10,375 companies operating in over 39 countries, the authors conclude to a mean value of total debt ratio equal to $22.64 \%$ for Germany. Using the GMM estimation method, the empirical findings report a negative and statistically significant effect of debt on firm performance.

Similar to the works of Harris and Raviv (1991), Simerly and Li (2000), Zeitun and Tian (2007), Margrates and 
Psillaki (2010) and Appiadjei (2014), Tristan and Huy (2015) manipulated the impact of debt maturity on firm performance. Investigating a sample of 147 firms from Vietnam over a period of 9 years from 2006 to 2014, the authors highlighted average values of return on assets, and return on equity equal to 0.1072 and 0.1723 , respectively. Moreover, these statistics show an average value of the total debt ratio of 0.476 with a minimum of 0.01 and a maximum of 0.98 . This result stimulates that most of the firms assets are obtained by using short-term and long-term capital structure. The empirical results manipulate a negative and a statistically significant impact of leverage on firm performance ( no difference between short-term capital structure and long term debt).

Following works of Akintoye (2009), Mehran (1995), Ang et al. (2000), Huang and Song (2006), and Chakraborty (2010), Sorana Vatavu (2015) identifies the impact of capital structure ratio on firm financial performance. The authors use three measures of debt ratios. Examining a sample of 196 Romania listed firms over a period from 2003 to 2010, the authors found mean values of return on assets, ROA, and return on equity, ROE, equal to -0.003 and 0.125 , respectively. Similarly, the average value of the total debt ratio is equal to 0.47 . However, this value is 0.089 for the long term and 0.38 for the short-term debt. Similarly, the correlation matrix presents a strong correlation between leverage approximations. For this reason, the author uses, alternatively these three ratios to avoid the multi co linearity problem. The authors found a negative and a statistically significant impact of total debt ratio and short-term debt ratio on firm performance approximated by ROA and ROE.

\section{Data and Methodology}

\subsection{Sample Selection}

The data in our sample are obtained from the «Mergentonline» DATABSAE. Our sample contains 116 firms of Malaysia and 92 firms of Mexico for a period of 7 years from 2005 to 2011.

\subsection{Choice of Variables and Hypothesis}

1) The dependent variable

Firm performance: To measure the profitability of the firms we use alternately two ratios:

- Return on assets ratio (ROA): We measure the return on assets as the net income to total assets ratio.

- Return on equity ratio (ROE): We measure the return on equity as the net result to shareholders' equity ratio.

2) Independent variables

The long-term debt ratio: Similarly to work Tristan and Huy-Cuong Nguyen (2015), we measure the long term capital structure ratio as the long-term over total assets ratio. Indeed, an increase amount of long-term debt will be invested. The study of the sign of this variable revealed two scenarios; if the financing cost is higher than return on investment projects, which might attenuate profitability. Otherwise, we conclude to a higher firm performance. Hypothesis 1: Long-term debt affects positively or negatively firm performance.

The short-term debt ratio: Following the work, we measure the short-term capital structure ratio as the short-term debt to total assets ratio. Short-term debts are generally not sufficient to bring short-term assets. Then, firms contract long-term debt, which will cause more financial expenses. In this case, the firm productivity become lower. Hypothesis 2: Short-term debt negatively affects firm performance.

The total debt ratio: According to work of Do Xuan and Zhong Xin (2014), we measure the total debt ratio as long-term debt increased by short-term debt divided by total assets. When the negative influence of short-term capital structure reward the positive influence of long-term debt; total debt negatively affects firms profitability. Otherwise, we estimate a contrary impact. Hypothesis 3: total debt can affect positively or negatively firm performance.

Firm size : Referring to Opler and Titman (1994), we approximate firm size by the logarithm of total revenues. The larger the size is, the greater growth opportunities of the firm are, which might increase firm profitability. Hypothesis 4: firm size positively affects the firm performance.

Assets Tangibility: Like Wiwattanakantang (1999), assets tangibility is estimated as tangible immobilisations divided by total assets. Tangible assets are considered as long-term investments. The more the firm makes more long-term investments, the more it can improve its operating management, and increase thus net incomes. Hypothesis 5: assets tangibility positively affects firm performance.

Age: According to the work George et al. (2012) we approximate the impact of age. Indeed, more the older the firm is, more the firm is positively reputed, which will positively explain shareholder wealth, and firm performance. Hypothesis 6: age positively explains firm performance. 
Growth opportunities: Similarly to the works of Opler and Titman (1994), we measure growth opportunities as growth rate of total revenues. Higher growth opportunities increase firm performance. Hypothesis 7: growth opportunities positively affect firm performance.

Table 1. Variables and expected signs

\begin{tabular}{cccc}
\hline Variables & Abbreviation & Formulation & Expected sign \\
\hline Firm performance & ROA & Net income/TA & Dependant variable \\
Firm performance & ROE & Net income / shareholders' equity & Dependant variable \\
Total debt ratio & TDR & (LTD+STD)/TA & Dependant variable. \\
Long term debt ratio & LTD & LTD/TA & $+/-$ \\
Short term debt ratio & STD & STD/TA & - \\
Growth opportunities & Growth & Growth rate of total revenues & + \\
Firm size & SIZE & Logarithm of total revenues & + \\
Firm age & AGE & number of years between the current date and the foundation year & + \\
Assets tangibility & TANG & Net PPE/TA & + \\
\hline
\end{tabular}

Note. TA: total assets. LTD: long term debt. STD: short term debt. PPE: property, plant and equipment.

\subsection{The models}

Following methodology of Do Xuan and Wu Zhong (2014) and Tristan and Huy-Cuong Nguyen (2015), we try to test following models to examine the effect of capital structure maturity on firm profitability (we use Stata and Eviews software).

$$
\begin{aligned}
R O A_{i t} & =\alpha_{0}+\alpha_{1} * L^{2}+R_{i t}+\alpha_{2} * \operatorname{SIZE}_{i t}+\alpha_{3} * T A N G_{i t}+\alpha_{4} * G R O W T H_{i t}+\alpha_{5} * A G E_{i t}+\varepsilon_{i t} \\
R O A_{i t} & =\alpha_{0}+\alpha_{1} * S D R_{i t}+\alpha_{2} * S I Z E_{i t}+\alpha_{3} * T A N G_{i t}+\alpha_{4} * G R O W T H_{i t}+\alpha_{5} * A G E_{i t}+\varepsilon_{i t} \\
R O A_{i t} & =\alpha_{0}+\alpha_{1} * T D R_{i t}+\alpha_{2} * S I Z E_{i t}+\alpha_{3} * T A N G_{i t}+\alpha_{4} * G R O W T H_{i t}+\alpha_{5} * A G E_{i t}+\varepsilon_{i t} \\
R O E_{i t} & =\alpha_{0}+\alpha_{1} * L D R_{i t}+\alpha_{2} * S I Z E_{i t}+\alpha_{3} * T A N G_{i t}+\alpha_{4} * G R O W T H_{i t}+\alpha_{5} * A G E_{i t}+\varepsilon_{i t} \\
R O E_{i t} & =\alpha_{0}+\alpha_{1} * S D R_{i t}+\alpha_{2} * S I Z E_{i t}+\alpha_{3} * T A N G_{i t}+\alpha_{4} * G R O W T H_{i t}+\alpha_{5} * A G E_{i t}+\varepsilon_{i t} \\
R O E_{i t} & =\alpha_{0}+\alpha_{1} * T D R_{i t}+\alpha_{2} * S I Z E_{i t}+\alpha_{3} * T A N G_{i t}+\alpha_{4} * G R O W T H_{i t}+\alpha_{5} * A G E_{i t}+\varepsilon_{i t}
\end{aligned}
$$

\section{The Empirical Results}

\subsection{Descriptive Statistics}

The description of our sample into five sectors: manufacturing sector, service sector, trade sector, mining and agriculture sector and real estate sector are presented in Table 2.

Table 2. Distribution of our sample into activity sectors

\begin{tabular}{ccccccc}
\hline & man & service & trade & Mining and agriculture & Real estate & Total \\
\hline Malaysia & 60 & 35 & 12 & 4 & 5 & 116 firms \\
Mexico & 40 & 20 & 19 & 6 & 7 & 92 firms \\
\hline
\end{tabular}

The sample of Malaysia is described as follow: 60 manufacturing firms, 35 companies in service sector, 12 firms in trade sector, 4 firms in mining and agriculture sector, 5 firms real estate sector. For the country of Mexico: 40 manufacturing firms, 20 companies in service sector, 19 firms in trade sector, 6 firms in mining and agriculture sector, 7 firms real estate sector.

The results of descriptive statistics are exposed in Table 3. the results highlight that firms in Malaysia have higher profitability ratio measured by, return on assets, ROA, with an average of 0,335 . However, firms in Mexico have higher profitability ratio measured by, return on equity, ROE, with an average of 0,0828 . However, the Malaysian firms have the smallest size with an average of 17,768. Firms in Mexico have more tangible assets. Firms in Mexico are the Mature companies (an average age of 43,406 years with a minimum of 5 year and a maximum of 165 years). A higher growth of total assets for firms from Malaysia (an average value of 0,231). Firms in Mexico have higher debt ratios approximated by the total debt ratio and the long term capital structure ratio. However, firms in Malaysia have higher short term debt ratio with an average value of 0,297. 
Table 3. Descriptive statistics

\begin{tabular}{|c|c|c|c|c|c|}
\hline \multicolumn{6}{|c|}{ Malysia } \\
\hline & OBS & MEAN & STD DEV & MIN & MAX \\
\hline ROA & 695 & 0,335 & 0,124 & $-0,964$ & 0,545 \\
\hline ROE & 678 & 0,0585 & 0,197 & $-0,999$ & 0,959 \\
\hline SIZE & 702 & 17,768 & 1,405 & 13,184 & 22,370 \\
\hline TANG & 702 & 0,297 & 0,202 & 0,00206 & 0,976 \\
\hline TDR & 522 & 0,454 & 0,267 & 0,00965 & 0,999 \\
\hline LDR & 686 & 0,0855 & 0,107 & 0 & 0,645 \\
\hline SDR & 686 & 0,297 & 0,183 & 0,00914 & 0,843 \\
\hline Growth & 580 & 0,231 & 1,411 & $-0,857$ & 23,366 \\
\hline Age & 469 & 25,880 & 17,787 & 2 & 105 \\
\hline \multicolumn{6}{|c|}{ Mexico } \\
\hline & OBS & MEAN & STD DEV & MIN & MAX \\
\hline ROA & 564 & 0,0436 & 0,0693 & $-0,277$ & 0,330 \\
\hline ROE & 549 & 0,0828 & 0,195 & $-0,883$ & 0,841 \\
\hline SIZE & 576 & 20,758 & 1,706 & 16,146 & 25,437 \\
\hline TANG & 571 & 0,416 & 0,205 & 0,0000767 & 0,807 \\
\hline TDR & 361 & 0,552 & 0,231 & 0,0197 & 0,993 \\
\hline LDR & 484 & 0,177 & 0,143 & 0 & 0,777 \\
\hline SDR & 568 & 0,247 & 0,157 & 0,00955 & 0,913 \\
\hline Growth & 483 & 0,0682 & 0,213 & $-0,756$ & 1,399 \\
\hline Age & 637 & 43,406 & 30,332 & 5 & 165 \\
\hline
\end{tabular}

\subsection{Effects of Debt Maturity on Firm Performance}

The findings on the effect of capital structure on firm performance are reported in the Table 4. Our model is estimated by two performance approximations. We used three measures of debt ratios: the long term debt ratio, the short term debt ratio and the total debt ratio.

Firm size: We conclude to a positive and a statistically significant effects for Malaysia and Mexico, when we considered as dependent variable return on assets, ROA, and when we considered as an approximation of performance return on equity, ROE. This finding do not rejects our hypothesis 4 . This result stimulates that the largest firms have more growth opportunities, and enhance firm productivity.

Assets tangibility: A negative and a statistically significant impact of tangibility on the firm performance, for Malaysia and Mexico market. This finding do not accept our hypothesis 5.This result stimulates that these firms have more tangible assets, but these assets are not well allocated.

The long-term debt ratio: Empirical validation of the influence of capital structure on firm performance show that for Malaysia and Mexico, the long-term debt ratio negatively affects firm performance ( except specification 5 for Mexico). This finding does not accept our first hypothesis. This finding do not rejects our hypothesis 3 .

The short-term debt ratio: We reported a negative and a statistically significant impact of short-term debt on firm performance approximated by return on assets, ROA and return on equity, ROE. This finding do not rejects our hypothesis 2 . This result stimulates that the short-term debts obtained to finance firm activities are not sufficient. Therefore, firms in Malaysia and Mexico are forced to undertake long-term debt to finance their deficits. The need for additional financing leads to additional financial expenses, which will decrease the firm productivity. To decrease the negative effect of short-term debt, firms can reduce its current assets by reducing credit sales, or increase its current liabilities by increasing its payables.

The total Debt ratio: The results show a positive and a statistically significant effect of the total debt ratio on firm performance in specification 4 for Malaysia, and a negative and a statistically significant effect in specifications 1 and 4 for Mexico, and specification 1 for Malaysia. The negative impact can be interpreted as follows: high levels of total debt implies a bankruptcy risk and higher agency costs. These additional agency costs will decrease profit of the firms. Furthermore, total debt is used to be invested in profitable investment projects. if the returns on these investment projects are greater than the agency costs related to total debt, we wait an enhance in profit. Otherwise, profit decrease.

Growth opportunities: The growth opportunities influence positively and significantly firm profitability. This 
result means more profitable opportunities improve firm performance.

Age: Older firms are highly efficient. This result is valid only in specification 2 for Malaysia, and specification 1 and 3 for Mexico. This finding do not rejects our hypothesis 6 . This result confirms the reputation of older firms, which will favourably affect performance. However, we report a negative and a statistically significant impact of age for specification 6 for Malaysia. This result may indicate the existence of agency problems within older firms of Mexico. Then, we can conclude that firms performance of Malaysia will deteriorate.

Table 4. Effects of debt maturity on firm performance

\begin{tabular}{|c|c|c|c|c|c|c|}
\hline \multicolumn{7}{|c|}{ Malysia } \\
\hline & Specification 1 & Specification 2 & Specification 3 & Specification 4 & Specification 5 & Specification 6 \\
\hline & ROA & ROA & ROA & ROE & ROE & ROE \\
\hline $\mathrm{C}$ & $-0,568^{* * *}$ & $-0,477^{* * *}$ & $-0,499^{* * * *}$ & $-0,965^{* * *}$ & $-0,700^{* * * *}$ & $-0,886^{* * *}$ \\
\hline SIZE & $0,0365^{* * *}$ & $0,0297^{* * *}$ & $0,0332^{* * *}$ & $0,0596^{* * *}$ & $0,0446^{* * *}$ & $0,0582^{* * *}$ \\
\hline TANG & $-0,0554^{* * *}$ & $-0,0558^{* * *}$ & $-0,0374^{* *}$ & $-0,0553^{* * *}$ & $-0,0403^{* *}$ & $-0,0654^{* * *}$ \\
\hline TDR & $-0,0312^{* * *}$ & & & $0,0340^{* * *}$ & & \\
\hline LDR & & $-0,100^{* * * *}$ & & & $-0,227^{* * *}$ & \\
\hline SDR & & & $-0,159^{* * *}$ & & & $-0,204^{* * * *}$ \\
\hline Growth & $0,0264^{* * *}$ & $0,0407^{* * *}$ & $0,0228^{* * *}$ & $0,0403^{* * *}$ & $0,0494^{* * *}$ & $0,0574^{* * *}$ \\
\hline Age & 0,0000613 & $0,000507^{* * * *}$ & 0,000248 & 0,0000998 & 0,00003 & $-0,000408^{* *}$ \\
\hline OBS & 233 & 328 & 323 & 234 & 320 & 314 \\
\hline $\begin{array}{l}\text { R squared(\%) } \\
\text { (wald chi2) }\end{array}$ & 269,15 & 205,55 & 226,88 & 668,34 & 379,57 & 378,09 \\
\hline Prob $>$ F & 0 & 0 & 0 & 0 & 0 & 0 \\
\hline \multicolumn{7}{|c|}{ Mexico } \\
\hline & Specification 1 & Specification 2 & Specification 3 & Specification 4 & Specification 5 & Specification 6 \\
\hline & ROA & ROA & ROA & ROE & ROE & ROE \\
\hline $\mathrm{C}$ & $-0,170^{* * *}$ & $-0,164^{* * *}$ & $-0,126^{* * *}$ & $-0,481^{* * *}$ & $-0,460^{* * *}$ & $-0,409^{* * *}$ \\
\hline SIZE & $0,0124^{* * *}$ & $0,0110^{* * *}$ & $0,0101^{* * * *}$ & $0,0297^{* * *}$ & $0,0272^{* * *}$ & $0,0301^{* * *}$ \\
\hline TANG & $-0,0380^{* * *}$ & $-0,0453^{* * *}$ & $-0,0474^{* * *}$ & $-0,0896^{* * *}$ & $-0,0758^{* * *}$ & $-0,105^{* * *}$ \\
\hline TDR & $-0,0536^{* * *}$ & & & $-0,0268^{*}$ & & \\
\hline LDR & & $-0,0753^{* * *}$ & & & 0,0345 & \\
\hline SDR & & & $-0,126^{* * *}$ & & & $-0,344^{* * *}$ \\
\hline Growth & $0,0386^{* * * *}$ & $0,0482^{* * * *}$ & $0,0587^{* * *}$ & $0,0960^{* * * *}$ & $0,0667^{* * * *}$ & $0,0648^{* * * *}$ \\
\hline Age & $0,000119^{* * *}$ & 0,000045 & $0,000119^{* * *}$ & 0,000173 & 0,000175 & 0,0000352 \\
\hline OBS & 297 & 396 & 466 & 297 & 375 & 449 \\
\hline $\begin{array}{l}\text { R squared(\%) } \\
\text { (wald chi2) }\end{array}$ & 423,91 & 223,88 & 2598,54 & 223,33 & 126,85 & 176,71 \\
\hline Prob $>$ F & 0 & 0 & 0 & 0 & 0 & 0 \\
\hline
\end{tabular}

\section{Role of Activity Sectors on the Effect of Capital Structure Maturity on Firm Performance}

Like Víctor M. González (2013) and Tristan and Huy-Cuong Nguyen (2015), we measure the effect of activity sectors in explaining the impact of debt maturity on firm productivity. We retain the return on asset ratio to measure productivity. Our results on the short term debt ratio confirms our research hypothesis. This result is valid for the manufacturing, service and trade sectors of firms from Malaysia, and the manufacturing, trade and agriculture and mining sectors for firms of Mexico. The results of the other specifications are not statistically significant. However, higher long term debt ratios lead to lower profitability ratios. The long term debt ratio negatively affects performance of firms from Malaysia operating in the service and trade sectors. The same result is found for manufacturing, service and agriculture and mining sectors for firms from Mexico. The influence of firm size is not statistically significant for firms of Malaysia belonging to real estate and agriculture and mining activities, and for firms of Mexico operating in the trade and agriculture and mining sectors. Growth opportunities have a negative impact on firm performance for firms in Malaysia operating in agriculture and mining activity sector. Other results confirm our research hypothesis. Finally, we found a negative relationship between firm age and corporate profitability for firms of Mexico belonging to trade and real estate activities. 
Table 5. Role of activity sectors in explaining the effects of debt maturity on firm performance

\begin{tabular}{|c|c|c|c|c|c|c|c|c|c|c|}
\hline \multicolumn{11}{|c|}{ Malysia } \\
\hline & \multicolumn{2}{|c|}{$\operatorname{man}$} & \multicolumn{2}{|c|}{ Service } & \multicolumn{2}{|c|}{ Trade } & \multicolumn{2}{|c|}{ Agri mining } & \multicolumn{2}{|c|}{ Real estate } \\
\hline & ROA & ROA & ROA & ROA & ROA & ROA & ROA & ROA & ROA & ROA \\
\hline $\mathrm{C}$ & $-0,726^{* * *}$ & $-0,725^{* * *}$ & $-0,551^{* * *}$ & $-0,446^{* * *}$ & $-0,00912$ & $-0,448^{* * *}$ & $-2,00824^{* *}$ & $-0,929$ & 0,122 & $-0,290$ \\
\hline SIZE & $0,0444^{* * *}$ & $0,0470^{* * * *}$ & $0,0330^{* * *}$ & $0,0289^{* * *}$ & $0,00786^{*}$ & $0,0342^{* * * *}$ & $0,141^{* *}$ & 0,0688 & $-0,00756$ & 0,0182 \\
\hline TANG & $-0,101^{* * *}$ & $-0,0505^{* *}$ & $-0,0562$ & $-0,0503$ & $-0,124^{* * *}$ & $-0,0690^{* *}$ & $-0,114$ & $-0,281$ & $-0,285$ & 1,732 \\
\hline LDR & 0,0164 & & $-0,146^{*}$ & & $-1,290^{* * *}$ & & $-0,891$ & & $-0,0917$ & \\
\hline SDR & & $-0,177^{* * *}$ & & $-0,111^{* * * *}$ & & $-0,294^{* * *}$ & & 0,0776 & & $-0,0365$ \\
\hline Growth & $0,0533^{* * *}$ & $0,0363^{* * *}$ & $0,0300^{* * *}$ & $0,0219^{* *}$ & 0,00662 & 0,0104 & $-0,0797^{*}$ & $-0,0339$ & 0,0393 & 0,0211 \\
\hline Age & $0,000635^{* * *}$ & $0,000412^{* *}$ & 0,000380 & $-0,000188$ & $-0,0000076$ & $-0,0000301$ & $-0,0113$ & $-0,00240$ & 0,000456 & $-0,00339$ \\
\hline OBS & 157 & 155 & 86 & 83 & 51 & 51 & 11 & 11 & 23 & 23 \\
\hline $\begin{array}{l}\text { Rsquared (\%) } \\
\text { (wald chi2) }\end{array}$ & 181,23 & 234,10 & 42,01 & 30,90 & 25,15 & 48,57 & 94,57 & 93 & 18,34 & 43,96 \\
\hline Prob> F & 0 & 0 & 0 & 0 & 0,0001 & 0 & 0 & 0 & 0,5761 & 0,0392 \\
\hline \multicolumn{11}{|c|}{ Mexico } \\
\hline & \multicolumn{2}{|c|}{ man } & \multicolumn{2}{|c|}{ Service } & \multicolumn{2}{|c|}{ Trade } & \multicolumn{2}{|c|}{ Agri mining } & \multicolumn{2}{|c|}{ Real estate } \\
\hline & ROA & ROA & ROA & ROA & ROA & ROA & ROA & ROA & ROA & ROA \\
\hline $\mathrm{C}$ & 0,0162 & 0,0318 & $-0,336^{* * *}$ & $-0,192^{* * *}$ & $1,0548^{*}$ & $-0,273^{* * *}$ & $-0,185$ & $0,527^{* * *}$ & $0,581^{* *}$ & $-0,560$ \\
\hline SIZE & $0,00376^{* *}$ & $0,00479^{* *}$ & $0,0201^{* * *}$ & $0,0127^{* * *}$ & $-0,0301$ & $0,0169^{* * * *}$ & 0,0140 & $-0,00483$ & $-0,0239^{*}$ & $0,0462^{*}$ \\
\hline TANG & $-0,0886^{* * *}$ & $-0,0886^{* * *}$ & $-0,0166$ & $-0,105^{* * *}$ & $-0,300^{* * * *}$ & $-0,0371^{* * *}$ & 0,0153 & $-0,506^{* * *}$ & $-0,0763$ & $-0,0614$ \\
\hline LDR & $-0,0917^{* * *}$ & & $-0,139^{* *}$ & & 0,0906 & & $-0,377^{* *}$ & & $-0,0664$ & \\
\hline SDR & & $-0,192^{* * *}$ & & $-0,00260$ & & $-0,0900^{* * *}$ & & $-0,526^{* * *}$ & & 0,0845 \\
\hline Growth & $0,0500^{* * *}$ & $0,0224^{* * *}$ & $-0,0168$ & 0,00592 & 0,0409 & 0,0232 & $0,111^{* * *}$ & $0,0865^{* * *}$ & $0,0707^{* * *}$ & 0,0189 \\
\hline Age & 0,000133 & 0,00000249 & 0,000129 & $0,000389^{*}$ & $-0,00496^{*}$ & $0,0000826^{*}$ & $-0,000333$ & $-0,0000873$ & $-0,000688^{* * *}$ & $-0,0114^{* * *}$ \\
\hline OBS & 152 & 198 & 88 & 100 & 81 & 94 & 35 & 35 & 33 & 36 \\
\hline $\begin{array}{l}\text { Rsquared (\%) } \\
\text { (wald chi2) }\end{array}$ & 57,85 & 102,39 & 12,52 & 52,50 & 16,08 & 156,53 & 17,09 & 46,04 & 50,09 & 60,05 \\
\hline Prob> F & 0 & 0 & 0,0283 & 0 & 0,0598 & 0 & 0,0043 & 0 & 0 & 0,0003 \\
\hline
\end{tabular}

Note. ${ }^{* * *, * * *}:$ significance at $10 \%, 5 \%$ and $1 \%$ levels respectively.

\section{Conclusion}

The aim of our paper is to identify the effect of debt ratios on firm performance. As a measure of capital structure we have considered three ratios: the long term capital structure, the short term capital structure and the total capital structure ratio. As dependant variables, we considered two approximations of firm performance: return on assets, and return on equity. A negative and a statistically significant impact of the short term and long term debt ratio on firm performance. A higher total debt ratio leads to a higher return on equity ratio for firms of Malaysia. Furthermore, a higher total debt ratio stimulates lower performance approximated by ROA and ROE, for specification 1 for Malaysia and specification 1 and 4 form Mexico. Regarding the impact of our control variables, we find evidence on the positive influence of size on firm performance for Mexico and Malaysia. we found a negative and a significant interdependence between assets tangibility and firm productivity. However, corporations with many growth opportunities are more profitable. Finally, only for Malaysia, older corporations are less profitable.

\section{References}

Abor, J. (2005). The effect of capital structure on profitability: An empirical analysis of listed firms in Ghana. Journal of Risk Finance, 6(5), 438-447. https://doi.org/10.1108/15265940510633505

Akintoye, I. R. (2009). Sensitivity of Performance to Capital Structure. Banking and Finance Letters, 1(1), 29-35.

Altman, E. I., \& Hotchkiss, E. S. (2006). Corporate financial distress and bankruptcy (3rd ed.). Hoboken, NJ: John Wiley \& Sons.

Andrade, G., \& Kaplan, S. N. (1998). How costly is financial (no economic) distress? Evidence from highly leveraged transactions that became distressed. Journal of Finance, 53, 1443-14931. https://doi.org/10.1111/0022-1082.00062 
Ang, J. S., Cole, R. A., \& Lin, J. W. (2000). Agency Costs and Ownership Structure. Journal of Finance, 55(1), 81-106. https://doi.org/10.1111/0022-1082.00201

Appiadjei, E. A. (2014). Capital Structure and Firm Performance: Evidence from Ghana Stock Exchange. Research Journal of Finance and Accounting, 5(16), 37-43.

Bris, A., Welch, I., \& Zhu, N. (2006). The costs of bankruptcy: Chapter 7 Liquidation versus Chapter 11 Reorganization. Journal of Finance, 61, 1253-13031. https://doi.org/10.1111/j.1540-6261.2006.00872.x

Chakraborty, I. (2010). Capital structure in an emerging stock market: The case of India. Research in International Business and Finance, 24(3), 295-314. https://doi.org/10.1016/j.ribaf.2010.02.001

Do, X. Q., \& Wu, Z. X. (2014). The Impact of Ownership Structure and Capital Structure on Financial Performance of Vietnamese Firms. International Business Research, 7(2), 2014. https://doi.org/10.5539/ibr.v7n2p64

George, A., Alexander, J., Brian, T. R., \& Carlos, P. B. (2012). Internationalization and Performance of Retail Firms: A Bayesian Dynamic Model. Journal of Retailing, 88(2), 191-205. https://doi.org/10.1016/j.jretai.2011.11.005

Hadlock, C., \& James, C. (2002). Do banks provide financial slack? Journal of Finance, 57, 1383-420. https://doi.org/10.1111/1540-6261.00464

Harris, M., \& Raviv, A. (1991). The Theory of Capital Structure. Journal of Finance, 46, 297-355. https://doi.org/10.1111/j.1540-6261.1991.tb03753.x

Huang, S., \& Song, F. (2006). The determinants of capital structure: evidence from China. China Economic Review, 17(1), 14-36. https://doi.org/10.1016/j.chieco.2005.02.007

Mahfuzah, S., \& Raj, Y. (2012). Capital Structure and Firm Performance: Evidence from Malaysian Listed Companies. Procedia - Social and Behavioral Sciences, 65, 156-166. https://doi.org/10.1016/j.sbspro.2012.11.105

Majumbar, S., \& Chhibber, P. (1999). Capital structure and performance: Evidence from a transition economy on an aspect of corporate governance. Public Choice, 98, 287-305. https://doi.org/10.1023/A:1018355127454

Margaritis, D., \& Psillaki, M. (2010). Capital Structure, Equity Ownership and Firm Performance. Journal of Banking and Finance, 34, 621-632. https://doi.org/10.1016/j.jbankfin.2009.08.023

Mehran, H. (1995). Executive compensation structure, ownership, and firm performance. Journal of Financial Economics, 38(2), 163-184. https://doi.org/10.1016/0304-405X(94)00809-F

Opler, T. C., \& Titman, S. (1994). Financial distress and corporate performance. Journal of Finance, 49(3), 1015-1040. https://doi.org/10.1111/j.1540-6261.1994.tb00086.x

Roden, D., \& Lewellen, W. (1995). Corporate capital structure decisions: Evidence from leveraged buyouts. Financial Management, 24, 76-87. https://doi.org/10.2307/3665536

Serghiescu, L., \& Vaidean, V. L. (2013). Determinant factors of the capital structure of a firm- An empirical analysis. Working paper EMQFB Tg Mures 2013.

Shleifer, A., \& Vishny, R. W. (1992). Liquidation values and debt capacity: A market equilibrium approach. Journal of Finance, 47, 1343-1366. https://doi.org/10.1111/j.1540-6261.1992.tb04661.x

Simerly, R. L., \& Li, M. (2000). Environmental dynamism, capital structure and performance: A theoretical integration and an empirical test. Strategic Management Journal, 21, 31-50. https://doi.org/10.1002/(SICI)1097-0266(200001)21:1<31::AID-SMJ76>3.0.CO;2-T

Sorana, V. (2015). The impact of capital structure on financial performance in Romanian listed companies. Procedia Economics and Finance, 32, 1314-1322. https://doi.org/10.1016/s2212-5671(15)01508-7

Tristan, N., \& Huy-Cuong, N. (2015). Capital Structure and Firms' Performance: Evidence from Vietnam's Stock Exchange. International Journal of Economics and Finance, 7(12), 2015.

Víctor, M. G. (2013). Leverage and corporate performance: International evidence. International Review of Economics and Finance, 25, 169-184. https://doi.org/10.1016/j.iref.2012.07.005

Wiwattanakantang, Y. (1999). An empirical study on the determinants of the capital structure of Thai firms. Pacific-Basin Finance Journal, 7, 371-403. https://doi.org/10.1016/S0927-538X(99)00007-4

Zeitun, R., \& Tian, G. (2007). Capital structure and corporate performance: Evidence from Jordan. Australasian 
Accounting Business and Finance Journal, 1, 40-53.

\section{Copyrights}

Copyright for this article is retained by the author(s), with first publication rights granted to the journal.

This is an open-access article distributed under the terms and conditions of the Creative Commons Attribution license (http://creativecommons.org/licenses/by/4.0/). 